\title{
The role of chemokines in mediating graft versus host disease: opportunities for novel therapeutics
}

\author{
Marina G. M. Castor ${ }^{1}{ }^{*}$, Vanessa Pinho $^{2}$ and Mauro M. Teixeira ${ }^{1}{ }^{*}$ \\ 1 Immunopharmacology, Department of Immunology and Biochemistry, Institute of Biological Sciences, Universidade Federal de Minas Gerais, Belo Horizonte, Brazil \\ ${ }^{2}$ Department of Morphology, Institute of Biological Sciences, Universidade Federal de Minas Gerais, Belo Horizonte, Brazil
}

Edited by:

Salvatore Cuzzocrea, University of

Messina, Italy

Reviewed by:

Marco Aurélio Martins, Oswaldo Cruz Foundation, Brazil

Miaozong Wu, Marshall University, USA

*Correspondence:

Marina G. M. Castor and Mauro M.

Teixeira, Laboratório de

Imunofarmacologia, Departamento

de Morfologia, Instituto de Ciências

Biológicas, Universidade Federal de

Minas Gerais, Avenida Antonio Carlos,

6627 - Pampulha, Belo Horizonte,

Minas Gerais 31270-901, Brazil.

e-mail:marinacastor@gmail.com
Bone marrow transplantation (BMT) is the current therapy of choice for several malignancies and severe autoimmune diseases. Graft versus host disease (GVHD) is the major complication associated with BMT.T lymphocytes and other leukocytes migrate into target organs during GVHD, become activated and mediate tissue damage. Chemokines are well known inducers of leukocyte trafficking and activation and contribute to the pathogenesis of GVHD. Here, we review the major animal models used to study GVHD and the role of chemokines in mediating tissue damage in these models. The role of these molecules in promoting potential beneficial effects of the graft, especially graft versus leukemia, is also discussed. Finally, the various pharmacological strategies to block the chemokine system or downstream signaling events in the context of GVHD are discussed.

Keywords: GVHD, chemokines, inflammation, therapy

\section{INTRODUCTION}

Allogeneic haematopoietic cell transplantation (HCT) is a transplant between two genetically non-identical individuals (Ferrara et al., 2009). It is an important therapeutic option to treat various malignant and non-malignant diseases, including acute and chronic leukemias, myelomas, lymphomas, aplastic anemias, solid tumors, and severe immunodeficiency disorders (Goker et al., 2001). The number of allogeneic HCTs performed annually worldwide is estimated to be more than 20,000 (Choi et al., 2010). After allogeneic HCT, some patients present with remission of primary disease. In some cases, patients may develop a common secondary complication in which transplanted cells reject the host tissues, named graft versus host disease (GVHD). GVHD accounts for $15-30 \%$ of deaths following allogeneic HCT and is a major cause of morbidity in up to $50 \%$ of transplant recipients (Ferrara et al., 2009).

Graft versus host disease manifests in two different forms, acute (aGVHD) and chronic (cGVHD). Acute GVHD occurs within 100 days of allogeneic HCT and is a rapidly progressive syndrome that is characterized by profound wasting, immunosuppression, and tissue injury in a number of organs, including the intestine, spleen, skin, liver, and lung (Howard and Woodruff, 1961; Lapp et al., 1985; Cooke et al., 1998; Wysocki et al., 2005; Socié and Blazar, 2009). In aGVHD, cytokines stimulate donor $\mathrm{T}$ cells to recognize host antigens that are presented by antigen-presenting cells (APCs). These T cells become activated and migrate to target organs where they generate effector responses against the host (reviewed by Wysocki et al., 2005; Jaksch and Mattsson, 2005). Unlike aGVHD, cGVHD occurs usually 100 days after bone marrow transplantation (BMT) and resembles an autoimmune syndrome (Will and Wynn, 2006). In addition to the effects mediated by $\mathrm{T}$ cells, cGVHD involves B-cell stimulation, autoantibody production, and systemic fibrosis (Schroeder and DiPersio, 2011). Although donor T cells may mount an effector response against the host cells, these cells also play a very important role in preventing the recurrence of the original malignant disease, especially when the HCT is given as a therapy for leukemia. These types of responses are referred to as graft versus leukemia (GVL; Johnson et al., 1996, 1999; Kolb, 2008). Thus, the inhibition of GVHD without interfering with GVL is of major interest therapeutically.

The management of GVHD is an old problem but is still unresolved. Standard therapy for GVHD includes high doses of corticosteroids, but the success of this therapy is not great, as mortality rates are more than $40 \%$ (Devetten and Vose, 2004; Ferrara and Reddy, 2006; Ferrara et al., 2009; Choi et al., 2010). In addition, patients that develop corticosteroid refractory GVHD have a high risk of death due either to GVHD itself or to secondary infections (Ferrara and Reddy, 2006). Although new therapies, including monoclonal antibodies against the IL-2 receptor (daclizumab), the TNF- $\alpha$ receptor (entanercept), or TNF- $\alpha$ (infliximab), and immunosuppressive drugs, such as mycophenolate mofetil, have been proposed to treat GVHD, these therapies are still not satisfactory (Choi et al., 2010). A better understanding of the mechanisms involved in the pathogenesis of GVHD may yield novel therapeutic targets. The present review discusses the role of chemokines and their receptors during GVHD.

Chemokines are a family of small proteins (about 8-14 kDa) that are classified into four major groups based on the number and spacing of conserved cysteines; the groups include the CC group (CCL1-28), the CXC group (CXCL1-16), the C group 
(XCL1-2), and the CX3C group (CX3CL1; Murphy et al., 2000; Murphy, 2002). Chemokines exert their effects through interaction with one or more members of a family of seven transmembrane domain-containing G-protein-coupled receptors (Zlotnik and Yoshie, 2000; Rot and Von Andrian, 2004; Charo and Ransohoff, 2006). There are currently 10 identified CC chemokine receptors (CCR1-10), $6 \mathrm{CXC}$ receptors (CXCR1-6), $1 \mathrm{C}$ receptor (XCR1), and $1 \mathrm{CX}_{3} \mathrm{C}$ receptor $\left(\mathrm{CX}_{3} \mathrm{CR} 1\right.$; Murphy et al., 2000; Murphy, 2002; Kittan and Hildebrandt, 2010; Russo et al., 2010). Chemokine expression can be enhanced by inflammatory cytokines (Mackay, 2001), and chemokines have an important role in recruiting cells of the innate and adaptive immune system to sites of inflammation (Rollins, 1997; Moser et al., 2004). In addition, chemokines have been suggested to be important for leukocyte activation (Choi et al., 2007), angiogenesis (Addison et al., 2000; Strieter et al., 2005), haematopoiesis (Broxmeyer, 2008), and the organization and function of secondary lymphoid tissues (Cyster, 1999; Muller et al., 2003; Ohl et al., 2003).

Understanding of the molecular mechanism involved in controlling expression of chemokine and their receptors in GVHD may provide efficient strategies to manage of disease. However, little is known about such mechanisms. Most studies report that the conditioning regime are a initial signal to trigger production of cytokines (such as TNF- $\alpha$, IFN- $\gamma$, IL-1, IL-2) and, consequently, up regulation of chemokine receptors and their ligands (Krenger et al., 1997; Jaksch and Mattsson, 2005; Wysocki et al., 2005; Mapara et al., 2006; Bouazzaoui et al., 2009; Kittan and Hildebrandt, 2010). TNF- $\alpha$ and IFN- $\gamma$ are produced during the initial phase of GVHD within lymphoid tissues and may induce production of chemokines in target organs by host cells (Schroeder and DiPersio, 2011). IFN- $\gamma$ is crucial for differentiation of CD $4^{+} \mathrm{T}$ cell into Th1 cells which increase the expression of CCR9, CCR5, and CXCR6u and their ligands in intestine and liver (Yi et al., 2009). IL2 is another important cytokine involved in $\mathrm{T}$ cell activation and expansion (Jaksch and Mattsson, 2005) and influences production of pro-inflammatory chemokines such as CCL2, CCL3, CCL4, CCL5 (Jaksch and Mattsson, 2005; Wysocki et al., 2005; Choi et al., 2007; Castor et al., 2010; Kittan and Hildebrandt, 2010). Therefore, the conditional regime and the cytokines associated with activation of T cells will provide the necessary stimuli for the production of chemokines, which in turn will promote and orchestrate the recruitment of immune cells during all phases of GVHD. Here, we reviewed chemokines involved in the pathogenesis of GVHD and discuss recent studies that have shown that interference in the chemokine system using antibodies and compounds may decrease the severity of GVHD while preserving the GVL response.

\section{MECHANISMS AND MODELS OF GVHD}

The pathogenesis of acute GVHD is currently understood as a three-phase response. The first phase is associated with the conditioning regimen (irradiation/chemotherapy) that leads to damage of host tissues, including the intestinal mucosa and liver (Ferrara, 1993; Hill et al., 1997; Jaksch and Mattsson, 2005; Mapara et al., 2006). The second phase is characterized by activation and proliferation of donor $\mathrm{T}$ cells. After transplantation, donor $\mathrm{T}$ cells interact with host APCs, recognize host antigens, become activated, and differentiate into effector cells (Jaksch and Mattsson,
2005; Wysocki et al., 2005). The greater the disparity between donor and recipient major histocompatibility complex (MHC), the greater the $\mathrm{T}$ cell response will be (Socié and Blazar, 2009). The interaction of T cells with APCs usually occurs in secondary lymphoid organs, including the spleen and lymph nodes (Zhang et al., 2005), but it can also occur in other peripheral lymphoid tissues, such as Peyer's patches (PP; Murai et al., 2003). In the third phase of the acute GVHD response, activated T cells migrate to target organs (intestine, liver, lung, and skin) and release cytolytic molecules and inflammatory cytokines, such as IFN- $\gamma$ and TNF$\alpha$, and undergo Fas/Fas ligand interactions (Baker et al., 1996; Braun et al., 1996; Cooke et al., 1998; Schmaltz et al., 2001; Jaksch and Mattsson, 2005). Recruitment of other effector leukocytes, including macrophages, follows $\mathrm{T}$ cell migration, and this process is thought to be important for the perpetuation of inflammatory responses and the destruction of target organs (Socié and Blazar, 2009; Castor et al., 2011; Schroeder and DiPersio, 2011).

Although the migration of $\mathrm{T}$ cells into secondary lymphoid organs during GVHD has been well characterized (Wysocki et al., 2005), the migration of leukocytes into parenchymal organs is less well understood. The latter process depends on interactions between selectins (Ley and Kansas, 2004; Luster et al., 2005; Carlson et al., 2010; Lu et al., 2010) and integrins (Hogg et al., 2002, 2003 ) and their ligands as well as on chemokine-chemokine receptor interactions (Wysocki et al., 2005; Castor et al., 2010; Kittan and Hildebrandt, 2010). Animal models of GVHD have provided important insights into the three characteristic phases of aGVHD.

\section{ANIMAL MODELS OF GVHD}

Although there are clear differences between human and experimental GVHD, the latter models are useful for performing mechanistic and kinetic studies and investigating changes in tissues. Most of the knowledge of the role of the immune system in the pathogenesis of experimental GVHD comes from experiments in mice (Schleuning, 2000; Shlomchik, 2007; Welniak et al., 2007; Ferrara et al., 2009; Schroeder and DiPersio, 2011).

The most relevant murine models of aGVHD (summarized in Table 1) involve transplantation of splenocytes and/or bone marrow cells and can vary depending on the irradiation dose used to ablate host immune cells. Models using total body irradiation (TBI), which is also referred to as myeloablative conditioning, require reconstitution of the immune system with the infusion of myeloid precursor cells. Usually, a dose of $5-10 \times 10^{6}$ cells is enough to repopulate the bone marrow compartment and ensure the survival of mice (Choi et al., 2011). An insufficient or inadequate reconstitution of bone marrow can result in death due to severe immunosuppression. In the early days following transplantation, mice that had been subjected to TBI usually have chimerism in their peripheral blood (i.e., they have a mixed population of donor and host cells). However, from day 7 after BMT, the donor haematopoietic cells have completely replaced the host cells (Choi et al., 2011). Partial irradiation or non-myeloablative conditioning does not require total bone marrow reconstitution. After transplantation, recipient mice demonstrate mixed chimerism, and the majority of the cells come from the donor (Choi et al., 2011).

In models in which mice are transplanted with a mix of allogeneic bone marrow cells and splenocytes, the animals usually 
Table 1 | Mouse models of graft versus host disease.

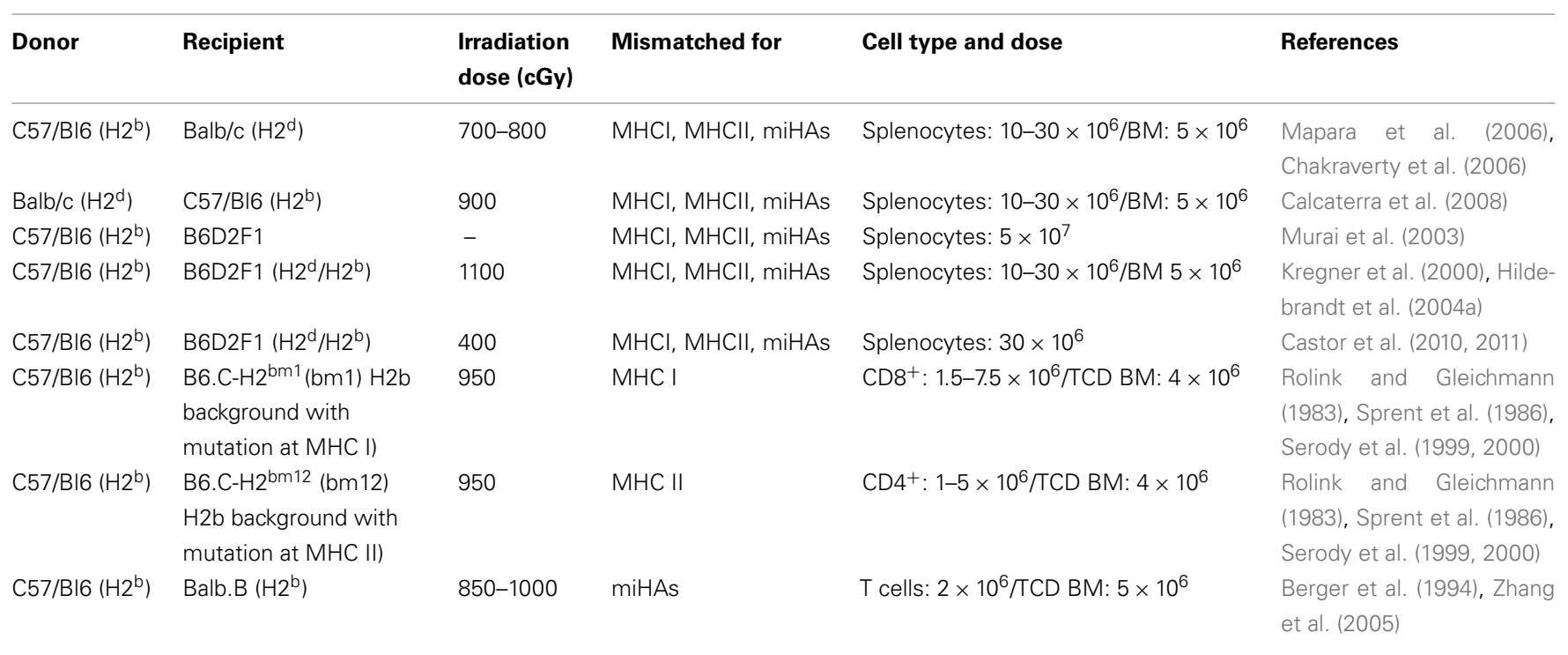

succumb to more severe disease than if they are only transplanted with bone marrow cells (Schroeder and DiPersio, 2011). Splenocytes represent a population of mature immune cells that are prepared to react against antigens when stimulated, whereas the bone marrow contains many immature immune cells that are not able to develop an appropriate response against antigens. Therefore, the response against host antigens in recipient mice is decreased when bone marrow cells rather than splenocytes are given (Schroeder and DiPersio, 2011). There is also a model of GVHD in which recipient mice are not irradiated. In this model, an infusion of $5 \times 10^{7}$ allogeneic cells is necessary to induce GVHD, and the disease is not lethal (Murai et al., 2003).

Another important consideration about the induction of GVHD in mice is the genetic origin of the donor cells. An allogeneic transplant is a transplant between MHC mismatched mice, such as $\mathrm{C} 57 / \mathrm{BL} 6\left(\mathrm{H} 2^{\mathrm{b}}\right)$ and $\mathrm{Balb} / \mathrm{c}\left(\mathrm{H}_{2}{ }^{\mathrm{d}}\right)$, in which there are disparities in MHCI, MHCII, and miHAs (Schroeder and DiPersio, 2011). The parental model of transplantation between C57/BL6 $\left(\mathrm{H} 2^{\mathrm{b}}\right)$ and $\mathrm{B} 6 \mathrm{D} 2 \mathrm{~F} 1\left(\mathrm{H} 2^{\mathrm{b} / \mathrm{d}}\right)$ mice, which is a result of the crossing of $\mathrm{C} 57 / \mathrm{BL} 6\left(\mathrm{H} 2^{\mathrm{b}}\right) \times \mathrm{DBA} / 2\left(\mathrm{H}_{2}{ }^{\mathrm{d}}\right)$ mice, also shows mismatches in MHCI, MHCII, and miHAs (Asavaroengchai et al., 2007; Castor et al., 2010, 2011). Semiallogeneic transplantation represents the transplantation between mice that are mismatched for MHCI, such as $\mathrm{C} 57 / \mathrm{BL} 6(\mathrm{H} 2 \mathrm{~b})$ and B6.C-H2 ${ }^{\mathrm{bm} 1}$ (bm1) mice, or between mice that are mismatched for MHCII, such as C57/BL6 (H2b) and B6.C-H2 ${ }^{\text {bm12 }}$ (bm12) mice (Rolink and Gleichmann, 1983; Sprent et al., 1986; Serody et al., 1999, 2000), or between mice that are mismatched for miHAs, such as C57/BL6 $\left(\mathrm{H}_{2}{ }^{\mathrm{b}}\right)$ and Balb.b $\left(\mathrm{H} 2^{\mathrm{b}}\right.$ ) mice (Berger et al., 1994; Zhang et al., 2005).

Another important consideration for the induction of GVHD is the dose and type of donor cells. The severity of disease is dependent on the number of donor cells that are infused, and the disease becomes more severe as the number of transferred cells increases (Schroeder and DiPersio, 2011). Finally, it is possible to inject different $\mathrm{T}$ cell subsets, such as $\mathrm{CD} 4^{+}, \mathrm{CD} 8^{+}$, and Treg cells, and NK cells, either separately or together. This strategy may be useful to dissect the differential role of these subsets during GVHD (Schroeder and DiPersio, 2011).

\section{CHEMOKINES IN GVHD AND POSSIBILITIES OF THERAPEUTIC APPROACHES}

Several studies have now described there is increased expression of chemokines and chemokine receptors in GVHD (New et al., 2002; Jaksch and Mattsson, 2005; Mapara et al., 2006; Bouazzaoui et al., 2009; Castor et al., 2011). The profile of chemokine and chemokine receptor expression is different in different target organs of GVHD. Table 2 and Figure 1 summarize the expression of chemokines and chemokine receptors in GVHD in various target organs and during different temporal phases of the disease.

\section{LYMPHOID ORGANS}

Soon after transplantation, donor cells migrate to secondary lymphoid organs and to lymphoid tissues associated with the mucosa, such as PP (New et al., 2002; Murai et al., 2003). CCR7, which is expressed on dendritic cells and naïve and central memory T cells, is responsible for the circulation of these cells between lymphoid organs in response to CCL19 and CCL21 and is therefore critical for the initiation of GVHD (Kittan and Hildebrandt, 2010). Three days after transplantation, CXCR3 ligands (CXCL9-11) are upregulated in secondary lymphoid tissues, and this event is followed by the upregulation of CCL2, CCL3, CCL4, and CCL5 (Wysocki et al., 2005). Upregulation of these ligands promotes the accumulation and activation of $\mathrm{T}$ cells in lymphoid tissue, but not in peripheral target organs, such as the liver and lung (Panoskaltsis-Mortari et al., 2000; Serody et al., 2000; Wysocki et al., 2004). CCR5 and CCR2 are also involved in the circulation of lymphocytes to lymphoid organs in GVHD. CCR5 expression in donor T cells plays a critical role in their accumulation in lymphoid tissues after allogeneic transplantation (Murai et al., 2003; Wysocki et al., 2004). In 2000, Serody et al. showed that eliminating the expression of a CCR5 ligand, CCL3, from donor T cells resulted in reduced CD8 ${ }^{+}$ accumulation in the spleen. In contrast, we have recently shown 
Table 2 | Chemokine and chemokine receptor expression in acute GVHD.

\begin{tabular}{|c|c|c|c|c|c|c|}
\hline \multirow[t]{2}{*}{ Chemokine } & \multirow{2}{*}{$\begin{array}{l}\text { Expression in } \\
\text { lymphoid tissues } \\
\text { (weeks after } \\
\text { transplant) } \\
\text { Spleen/lymph nodes }\end{array}$} & \multicolumn{4}{|c|}{$\begin{array}{l}\text { Expression in target organs } \\
\text { (weeks after transplant) }\end{array}$} & \multirow[t]{2}{*}{ References } \\
\hline & & Intestine & Liver & Lung & Skin & \\
\hline CXCL1 & & - & $+(1-3,6)$ & $+(1,2)$ & $+(1,2)$ & Bouazzaoui et al. (2009), Kittan and Hildebrandt (2010) \\
\hline CXCL10 & $+(1)$ & $+(1)$ & $+(1-3)$ & $+(1-3,6)$ & $+(1,2)$ & $\begin{array}{l}\text { Bouazzaoui et al. (2009), Kittan and Hildebrandt (2010), } \\
\text { Wysocki et al. (2005) }\end{array}$ \\
\hline CXCL11 & $+(1)$ & $+(1-3,6)$ & $+(1-3,6)$ & $+(1-3)$ & $+(1,2)$ & $\begin{array}{l}\text { Bouazzaoui et al. (2009), Kittan and Hildebrandt (2010), } \\
\text { Wysocki et al. (2005) }\end{array}$ \\
\hline CCL3 & $+(1)$ & $+(1-3,6)$ & $+(1-3,6)$ & $+(1-3,6)$ & & $\begin{array}{l}\text { Bouazzaoui et al. (2009), Wysocki et al. (2005), Castor } \\
\text { et al. (2011), Serody et al. (1999) }\end{array}$ \\
\hline CCL4 & $+(1)$ & - & $+(1-3,6)$ & $+(1-3,6)$ & & Wysocki et al. (2005) \\
\hline CCL5 & $+(1)$ & $+(1,2,3)$ & $+(1-3,6)$ & $+(1-3,6)$ & $+(1,2)$ & $\begin{array}{l}\text { Bouazzaoui et al. (2009), Wysocki et al. (2005), Castor } \\
\text { et al. (2011), Choi et al. (2007) }\end{array}$ \\
\hline CCL6 & & & & & $+(1,2)$ & Reiss et al. (2001) \\
\hline CCL7 & & & & & $+(1,2)$ & Reiss et al. (2001) \\
\hline CCL8 & & - & - & $+(1-3,6)$ & $+(1,2)$ & Bouazzaoui et al. (2009) \\
\hline CCL9 & & & & & $+(1,2)$ & Kittan and Hildebrandt (2010) \\
\hline CCL11 & & & & & $+(1,2)$ & Kittan and Hildebrandt (2010) \\
\hline CCL12 & & & $+(1-3)$ & $+(1-3,6)$ & $+(1,2)$ & Bouazzaoui et al. (2009), Kittan and Hildebrandt (2010) \\
\hline \multicolumn{7}{|c|}{ CHEMOKINE RECEPTORS } \\
\hline CXCR2 & & - & $+(2,3)$ & - & & Bouazzaoui et al. (2009) \\
\hline CXCR3 & $+(1)$ & $+(1,2,6)$ & $+(1)$ & $+(1-3)$ & $+(1,2)$ & $\begin{array}{l}\text { Bouazzaoui et al. (2009), Kittan and Hildebrandt (2010), } \\
\text { Wysocki et al. (2005) }\end{array}$ \\
\hline CXCR6 & & $+(1-3,6)$ & $+(1-3)$ & $+(1-3,6)$ & & Bouazzaoui et al. (2009), Ueha et al. (2007) \\
\hline CCR1 & & $+(1-3,6)$ & $+(1,2,3)$ & $+(1,2)$ & $+(1,2)$ & $\begin{array}{l}\text { Bouazzaoui et al. (2009), Kittan and Hildebrandt (2010), } \\
\text { Choi et al. (2007), Ueha et al. (2007) }\end{array}$ \\
\hline CCR2 & $+(1)$ & $+(1,2)$ & $+(2,3)$ & $+(3)$ & $+(1,2)$ & $\begin{array}{l}\text { Bouazzaoui et al. (2009), Kittan and Hildebrandt (2010), } \\
\text { Wysocki et al. (2005), Ueha et al. (2007), Terwey et al. } \\
\text { (2005) }\end{array}$ \\
\hline CCR4 & & & & & $+(2)$ & Reiss et al. (2001) \\
\hline CCR5 & $+(1)$ & $+(1,3,6)$ & $+(1,2,3)$ & $+(2)$ & $+(1,2)$ & $\begin{array}{l}\text { Bouazzaoui et al. (2009), Kittan and Hildebrandt (2010), } \\
\text { Wysocki et al. (2005), Ueha et al. (2007), Murai et al. } \\
\text { (1999) }\end{array}$ \\
\hline CCR6 & & $+(1,2,3)$ & & & & Varona et al. (2006) \\
\hline CCR10 & & & & & $(1,2)$ & Reiss et al. (2001) \\
\hline XCR1 & & - & $+(2,3)$ & $+(2,3)$ & $+(1,2)$ & Bouazzaoui et al. (2009), Kittan and Hildebrandt (2010) \\
\hline $\mathrm{CX}_{3} \mathrm{CR} 1$ & & $+(1,2)$ & & & & Ueha et al. (2007) \\
\hline
\end{tabular}




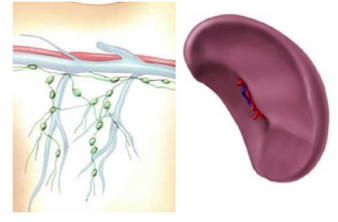

Lymphoid organs

Chemokine expression: CXCL9,CXCL10, CXCL11, CCL2,CCL3, CCL4, CCL5, CCL19, CCL21 Chemokine receptors expression:

CXCR3, CCR2, CCR5

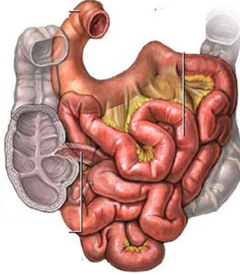

Intestine

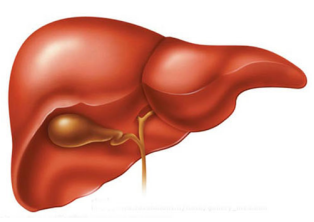

Liver

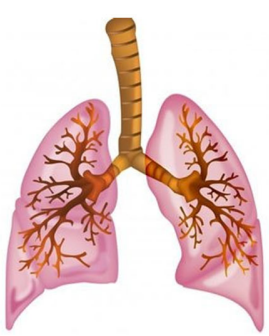

Lung

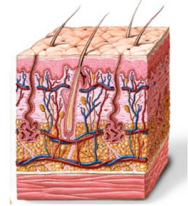

Skin
Chemokine expression: CXCL9,CXCL10, CXCL11, CXCL16, CCL2,CCL3, CCL5, CCL20, $\mathrm{XCL} 1$,

CX3CL1

Chemokine receptors expression:

CXCR3, CXCR6, CCR1, CCR2, CCR5, CCR6, CX ${ }_{3} \mathrm{CR} 1$
Chemokine expression: CXCL1,CXCL9,CXCL10, CXCL11, CXCL16, CCL2,CCL3, CCL4, CCL5, CCL12,CCL20,

XCL1

Chemokine receptors expression: CXCR2,CXCR3, CXCR6, CCR1, CCR2, CCR5, XCR1
Chemokine expression: CXCL1,CXCL2,CXCL9, CXCL10, CXCL11, CCL2, CCL3, CCL4, CCL5, CCL8,CCL12, $\mathrm{XCL} 1$

Chemokine receptors expression:

CXCR3,CXCR6, CCR1, CCR2, CCR $5, X \mathrm{CR} 1$
Chemokine expression: CXCL1,CXCL2,CXCL9, CXCL10, CXCL11,

CCL2,CCL5,

CCL6,CCL7,CCL8, CCL9, CCL11,CCL12, CCL17, CCL19,CCL20,CCL27, XCL1

Chemokine receptors expression: CXCR3, CCR1, CCR2, CCR4,CCR5, CCR10,XCR1

FIGURE 1 | Overview of chemokine and chemokine receptor expression in the major organs targeted by GVHD. Shown are the major target organs that are affected by GVHD, the intestine, liver, lung, and skin, and the major chemokines and chemokine receptors that are expressed during the course of the disease.

that CCL3 in donor cells is not important for $\mathrm{CD}^{+}$and $\mathrm{CD} 4^{+}$ accumulation in the spleen, but it is important for their accumulation in the intestine (Castor et al., 2010). Additionally, others studies have shown that CCR 5 expression or CCL3 production by $\mathrm{T}$ cells is not important for their accumulation in PP and spleen (Panoskaltsis-Mortari et al., 2000; Welniak et al., 2004; Wysocki et al., 2004). CCR2 expression did not affect the accumulation of $\mathrm{CD}^{+}$cells in the spleen, but it increased their activation, changed the disease profile from chronic to acute GVHD and promoted the death of GVHD mice (Rao et al., 2003).

\section{TARGET ORGANS}

\section{CXC chemokine subfamily}

After the accumulation and activation of donor cells in secondary lymphoid organs, these cells migrate to target organs (Wysocki et al., 2005). CXCR3 and its ligands, CXCL9-11, are expressed in the target organs of GVHD (liver, intestine, lung, and skin) and are associated with the migration and maintenance of CXCR3 ${ }^{+}$ donor cells in these organs (Duffner et al., 2003; Mapara et al., 2006; Bouazzaoui et al., 2009). Elimination of CXCR3 from donor cells or neutralization of its ligands reduces disease in the above organs (Flier et al., 2001; Wysocki et al., 2005; Piper et al., 2007; Kittan and Hildebrandt, 2010). As a result of this, several patent applications for CXCR3 antagonists have been made, but none have yet been approved for clinical use to treat GVHD and other diseases in which CXCR3 participates (Pease and Horuk, 2009). Considering the high expression of CXCR3 ligands in target organs of GVHD (Duffner et al., 2003; Mapara et al., 2006; Bouazzaoui et al., 2009), another novel therapeutic strategy is the use of CXCR3-transfected Treg cells, which function as modulators of
GVHD development (Hasegawa et al., 2008). In this study, chemotactic signals for CXCR3 attracted regulatory cells to target tissues, resulting in decreased GVHD severity (Hasegawa et al., 2008).

The role of CXCR4 in GVHD is not completely understood, but CXCR4 is a chemokine receptor that interacts with chemokine stromal-derived factor-1 (SDF-1/CXCL12) and regulates haematopoietic stem and progenitor cell (HSPC) trafficking (Moll and Ransohoff, 2010). Disruption of this interaction either through cleavage of SDF-1 and CXCR4 or downregulation of SDF1 expression results in the rapid egress of HSPCs from the bone marrow (Broxmeyer et al., 2005; Semerad et al., 2005; Moll and Ransohoff, 2010). Mobilization of HSPCs from the bone marrow to the peripheral blood has become the standard method to collect allografts from healthy related donors for transplantation into patients with haematologic malignancies (Greenbaum and Link, 2011). This procedure is associated with more rapid engraftment, shorter hospital stay, and in some circumstances, superior overall survival in comparison to unmanipulated bone marrow (Greenbaum and Link, 2011). AMD3100 (Plerixafor; Genzyme, Cambridge, MA, USA) is a small bicyclam molecule that functions as a reversible inhibitor of SDF-1 binding to CXCR4 (Proudfoot et al., 2010). Studies in murine models, healthy human volunteers, and patients have demonstrated a dose-dependent increase in HSPC mobilization within a few hours of AMD3100 administration. Thus, AMD3100 is emerging as a new drug for the management of HSCT (Devine et al., 2008; Pusic and DiPersio, 2008). No prophylactic effect of AMD3100 has been described in relation to GVHD, but based on the prophylactic results obtained with other agents, such as G-CSF, that mobilize HSPCs, this possibility should be investigated. 
CXCR6 and CXCL16 are other CXC chemokines that are increased in the liver and intestine in GVHD. However, the role of these molecules in the pathophysiology of GVHD is not clear (Bouazzaoui et al., 2009). Some studies have shown an increased expression of CXCR6 on CD8 ${ }^{+}$T cells that contributed to the early recruitment of these cells to the liver (Sato et al., 2005; Ueha et al., 2007).

Elevated expression levels of CXCL1, CXCL2, and the CXCR2 receptor were also found in the liver, lung, and skin of mice subjected to GVHD. However, the role of these chemokines and chemokine receptor was not completely elucidated and should be explored in future studies.

\section{CC chemokine subfamily}

Chemokines of the CC subfamily, especially CCL2, CCL3, CCL4, and CCL5, have been described to be important for the migration of donor cells to target organs during GVHD development.

Some studies have shown increased levels of CCL2 early on in the liver (Ichiba et al., 2003) and intestine (Castor et al., 2011) of mice subjected to GVHD, but the role of this chemokine is not clear. Increased levels of CCL2 contribute to the migration of donor monocytes and macrophages to the lung as shown by studies in which neutralization of CCL2 or absence of CCR2 on donor cells resulted in reduced inflammatory infiltrates in the lung and consequently, minor lung injury (Hildebrandt et al., 2004b). The CCL2 receptor, CCR2, has an important role in the activation and migration of $\mathrm{CD}^{+} \mathrm{T}$ cells in the intestine and liver during GVHD (Terwey et al., 2005). CCR2 is also involved in lung damage (Hildebrandt et al., 2003, 2004b,c, 2005). Chemokines produced by $\mathrm{T}$ cells, such as CCL3 and CCL5, and cytokines, such as TNF- $\alpha$, enhance the recruitment of $\mathrm{CCR} 2^{+}$macrophages to the lung; macrophages produce more TNF- $\alpha$ and thus perpetuate the inflammatory response (Serody et al., 2000; Hildebrandt et al., 2003, 2004b,c, 2005).

Three days after transplantation, CCL3 levels are already high in the intestine of mice subjected to GVHD after sublethal conditioning. The initial production of CCL3 is mostly derived from host cells, but its production then switches to transplanted cells. Indeed, 10 days after transplantation, donor cells were the major source of CCL3 in the target organs of mice subjected to GVHD (Serody et al., 1999; Castor et al., 2010). In 2010, our group showed the effect of a chemokine binding protein, evasin-1, in a model of GVHD in mice. Evasin-1 bound with high affinity to CCL3 $\left(K_{\mathrm{d}} 0.16 \mathrm{nM}\right)$ and prevented its association with CCR1 or CCR5 (Frauenschuh et al., 2007). Neutralization of CCL3 by evasin1 decreased GVHD mortality and damage to the intestine and liver and reduced the infiltration of $\mathrm{CD} 4^{+}$and $\mathrm{CD} 8^{+}$cells and macrophages in the intestine. There was also a reduction in CCL5 levels in the intestine after CCL3 neutralization, suggesting that CCL3 may upregulate CCL5 in this organ (Castor et al., 2010). The CCL5:CCR1 interaction also contributes to target organ injury, as blockade of this interaction resulted in suppression of alloreactive $\mathrm{T}$ cell activation, leading to decreased liver and intestinal injury (Choi et al., 2007).

As suggested by clinical and experimental studies, CCR5 is a critical receptor that is associated with GVHD development. After stimulation by donor cell CCL3, CCL4, and CCL5, CCR5 promote the recruitment of alloreactive $\mathrm{T}$ cells to the intestine, resulting in the perpetuation of the inflammatory response in this organ and increased GVHD mortality (Wysocki et al., 2005; Choi et al., 2007). Besides modulating mortality and the recruitment of donor T cells to target organs in experimental GVHD (Murai et al., 2003), CCR5 appears to be important in controlling skin injury in humans with GVHD by promoting the recruitment of T cells to this site (Palmer et al., 2010). CCR5 is a major receptor that recruits lymphocytes to the skin of humans with GVHD and contributes to the production of TNF- $\alpha$, IL-2, and IFN- $\gamma$, which participate in the pathogenesis of human GVHD (Palmer et al., 2010). Studies have shown that loss of CCR5 function by a 32-nucleotide deletion (CCR5 $\Delta 32)$ in patients undergoing allogeneic BMT resulted in a decreased incidence of GVHD (Bogunia-Kubik et al., 2006). Furthermore, the presence of the CCR5 $\Delta 32$ genotype in both recipient and donor cells displayed the highest protection (Bogunia-Kubik et al., 2006). Thus, CCR5 may be an interesting target in GVHD. Although maraviroc, which is an inhibitor of CCR5, has been approved by the FDA for clinical use, no study has validated its use in GVHD management.

CCL25 demonstrates protective properties in GVHD. Interaction of CCL25 with its receptor, CCR9, leads to the induction of regulatory $\mathrm{T}$ cells and suppresses antigen-specific immune responses that are associated with GVHD (Hadeiba et al., 2008). On the other hand, CCR9 has also been identified as a critical homing receptor for lymphocytes into inflamed intestine, a process that contributed to the development of intestinal diseases, such as colitis and Crohn's disease (Saruta et al., 2007). Considering that CCR9 contributes to intestinal inflammatory diseases, an orally bioactive inhibitor of CCR9, CCX282, was developed. CCX282 is now in Phase III of clinical trials (Pease and Horuk, 2009; Proudfoot et al., 2010) and will be a promising approach for the treatment of intestinal GVHD.

CCL20:CCR6 interactions also appear to be relevant in GVHD. Interaction of CCL20 with its receptor, CCR6, induces the recruitment of alloreactive $\mathrm{CD}^{+}$cells to the intestine, liver, and skin of mice that had been subjected to allogeneic transplantation. Infusion of CCR6-deficient cells resulted in reduced tissue damage and disease severity (Varona et al., 2006). Alloreactive T cells can produce CCL20, which can interact with CCR6 expressed on the surface of Langerhans cells. Langerhans cells are the major APC in the skin and are involved in the pathogenesis of cutaneous GVHD (Merad et al., 2002, 2004). Host Langerhans cells can persist for several months in the skin and are responsible for the onset of skin GVHD by interacting with donor T cells (Durakovic et al., 2006). In addition, alloreactive $T$ cell production of CCL20 may attract donor Langerhans cells to the skin, leading to local presentation of host antigens and injury to the skin (Merad et al., 2002, 2004). Another mediator that has relevance to human cutaneous GVHD is CCL27 and its receptor, CCR10. Levels of CCL27 and CCR10 were increased in the skin of patients with GVHD and were associated with the migration of alloreactive T cells to this organ (Reiss et al., 2001; Faaij et al., 2006). CCL20:CCR6 and CCL27:CCR10 have been shown to play an important role in GVHD in target organs, mainly the skin. However, there have been no studies investigating therapeutic strategies to control the release or action of these molecules in GVHD. 
In the $\mathrm{CC}$ chemokine subfamily, other members have been found to be increased in GVHD target organs, such as CCL7, CCL8, CCL9, CCL11, CCL12, CCL19, and their respective receptors; however, the exact role of these chemokines in the development of GVHD is not understood.

\section{XCL and CX3CL subfamily}

$\mathrm{XCL} 1$ is a chemokine whose expression is frequently increased in GVHD target organs, but its function has not yet been explored. Bouazzaoui et al. (2009) showed increased levels of XCL1/XCR1 in the intestine, liver, lung, and skin during the course of GVHD. However, no information is available on the role of these molecules in GVHD development, which could be exciting for future studies.

Fractalkine, or CX3CL1, is the unique member of the CX3CL family and is also involved in GVHD. High levels of CX3CL1 were detected in the intestine of mice that had been subjected to GVHD. Increased levels of this chemokine were associated with the recruitment of $\mathrm{CD}^{+} \mathrm{T}$ cells to the intestine that contributed to intestinal damage (Ueha et al., 2007). Treatment with an anti-CX3CL1 antibody reduced the number of $\mathrm{CD}^{+} \mathrm{T}$ cells in the intestine of mice, resulting in improved survival and clinical disease (Ueha et al., 2007).

Considering the important role of many chemokines in facilitating GVHD development, Grainger and Reckless (2003) demonstrated an alternative way to control the action of chemokines in GVHD. The group used oligopeptides, which acted as functional chemokine inhibitors. One member of this group, NR58-3.14.3, suppressed both in vivo and in vitro migration of leukocytes to CCL2, CXCL8, CCL3, and CCL5 (Reckless et al., 2001). These oligopeptides were successfully tested in mouse models of GVHD, resulting in reduced clinical disease, decreased inflammatory infiltration, and less damage to the liver and lung (Miklos et al., 2009).

The data above suggest that chemokines and their receptors represent promising molecules to be explored as therapeutic targets to modulate GVHD. Future research will reveal additional details surrounding the efficiency of these therapeutic strategies in the control of the inflammatory responses that are associated with GVHD.

\section{DOWNSTREAM SIGNALING OF CHEMOATTRACTANT RECEPTORS AND GVHD}

Signaling by chemokine receptors is mediated by heterotrimeric G-proteins (Horuk and Proudfoot, 2009). Activation of G-proteins leads to activation of protein and lipid kinases, including mitogenactivated protein (MAP), Janus kinase-signal transducer and activator of transcription (JAK-STAT), and phosphatidyl inositol-3kinase $\left(\mathrm{PI}_{3} \mathrm{~K}\right)$, which mediate actin cytoskeleton rearrangement, changes in integrin affinity and avidity, leukocyte migration and proliferation, and cellular differentiation and apoptosis (Ribas et al., 2007; Russo et al., 2010).

Recent studies have attempted to elucidate the role of molecules downstream of chemokine receptor signaling and to establish a functional hierarchy involved in the development of GVHD, represented in Figure 2 (Cetkovic-Cvrlje et al., 2001, 2002; CetkovicCvrlje and Uckun, 2004; Sun et al., 2004, 2005; Hill et al., 2010;
Park et al., 2010; Castor et al., 2011; Ma et al., 2011). Modulation of these downstream signaling molecules is an alternative way to interfere with the chemokine/chemokine receptor system.

We have recently evaluated the role of $\mathrm{PI}_{3} \mathrm{~K} \gamma$ in the development of GVHD (Castor et al., 2011). $\mathrm{PI}_{3} \mathrm{~K} \gamma$ in donor cells was relevant for the initial surge of chemokine production in the target organs of mice subjected to GVHD. In addition to production of proinflammatory mediators in target tissues, infiltration of $\mathrm{CD}^{+}$, $\mathrm{CD}^{+}$, and $\mathrm{CD} 11 \mathrm{c}^{+}$cells was decreased with the absence of $\mathrm{PI}_{3} \mathrm{~K} \gamma$ in donor cells, and pharmacological blockade of $\mathrm{PI}_{3} \mathrm{~K} \gamma$ was associated with decreased rolling and adhesion of leukocytes to target organs as assessed by intravital microscopy. These effects on cell recruitment were translated as overall clinical improvement and decreased lethality in the absence of $\mathrm{PI}_{3} \mathrm{~K} \gamma$ or its pharmacological inhibition in donor cells (Castor et al., 2011).

Phosphorylation of ERK-1/2 and STAT-3 are involved in important events during $\mathrm{T}$ cell (allo) activation in GVHD, and interference with STAT-3 phosphorylation can inhibit T cell activation and proliferation in GVHD both in vitro and in vivo ( $\mathrm{Lu}$ et al., 2008). Additionally, expansion of $\mathrm{CD}^{+}$and $\mathrm{CD}^{+} \mathrm{T}$ cells depends on the expression of phospho[p]-STAT-1 and p-STAT-3. GVHD-specific STAT-3/STAT-1 activation preceded the activation of nuclear factor- $\kappa \mathrm{B}(\mathrm{NF}-\kappa \mathrm{B})$ and MAP kinases and was associated with the subsequent expression of interferon regulatory factor-1 (IRF-1), suppressor of cytokine signaling 1 (SOCS-1) and IL-17 (Ma et al., 2011). STAT-1 expression in the spleen preceded its expression in target organs and was correlated with the chemokine storm in these organs. STAT-3 expression was similar to that of STAT-1 and was observed early in secondary lymphoid organs and later in target tissues. In the spleen, STAT-3 expression was correlated with high levels of IL- 6 and IL-10. The marked change in the IL-6/IL-10 ratio during the development of GVHD suggests that STAT-3 may act as a promoter of inflammation during the early priming and induction phase of GVHD (high IL-6/IL10 ratio) but may mediate anti-inflammatory signals at later time points (low IL-6/IL-10 ratio; Ma et al., 2011). By contrast, early inhibition of NF- $\kappa \mathrm{B}$ may reduce GVHD by affecting primarily the haematopoietic compartment with inhibition of donor $\mathrm{T}$ cell expansion or host APC maturation. However, delayed inhibition of NF- $\mathrm{B}$ may interfere with target tissue regeneration or promotion of inflammation, leading to worsening of GVHD (Sun et al., 2004, 2005). Interestingly, cytokine signaling through JAKSTAT-3 in GVHD was regulated by SOCS-3 (Hill et al., 2010). Transplantation of donor T cells into SOCS-3 deficient mice led to persistent phosphorylation of STAT-3, resulting in enhanced T cell proliferation, greater Th1 and Th17 differentiation, and production of IFN- $\gamma$ and IL-17 (Hill et al., 2010). Thus, SOCS-3 has a regulatory effect and is an attractive target for GVHD therapeutic modulation; functional augmentation of SOCS-3 may preferentially inhibit alloreactive $\mathrm{T}$ cell proliferation and differentiate cells away from pathogenic Th17/Th1 pathways. Janus kinase signaling occurs downstream of chemokine receptor signaling, and there are molecules that inhibit this pathway. One such inhibitor, CP690550 , was found to decrease mortality and reduce target organ damage in mice subjected to GVHD by suppressing donor CD $4^{+}$ $\mathrm{T}$ cell-mediated (IFN) $-\gamma$ production and inhibition of Th1 differentiation (Park et al., 2010). Specific inhibitors of Janus kinase 


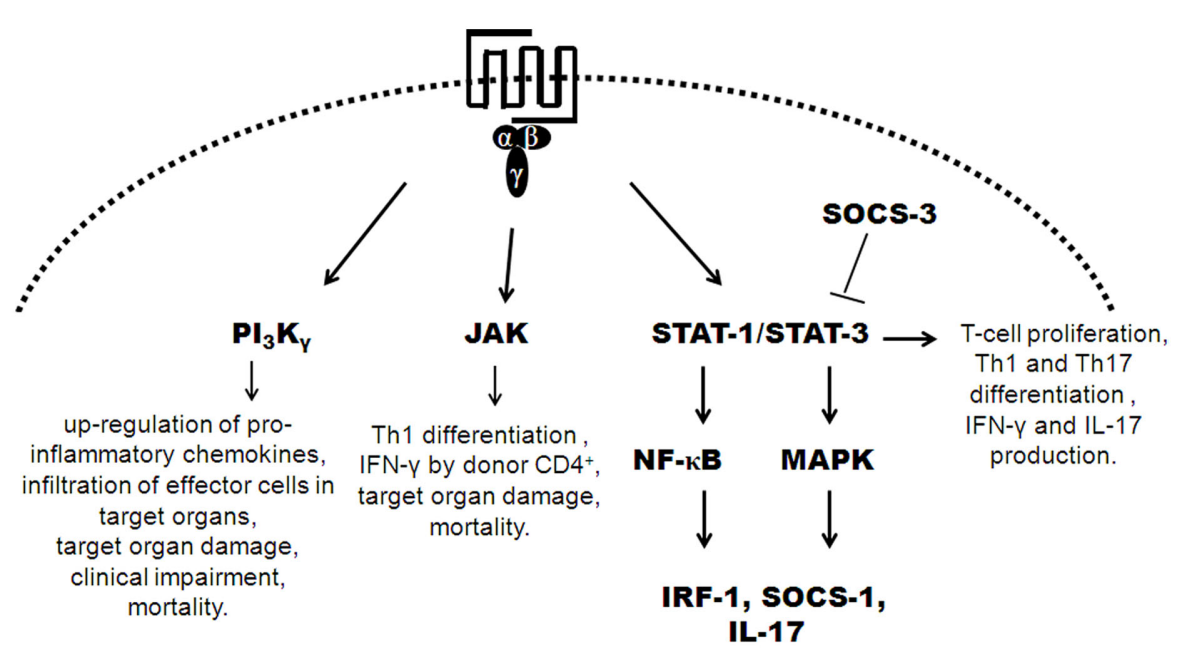

\begin{tabular}{|c|c|}
\hline \multicolumn{2}{|c|}{$N F-k B$ in GVHD } \\
\hline early & late \\
\hline $\begin{array}{l}\text { donor T-cell expansion } \\
\text { or host APC maturation. }\end{array}$ & $\begin{array}{c}\text { target tissue regeneration, } \\
\text { promotion of inflammation, } \\
\text { worsening of GVHD. }\end{array}$ \\
\hline
\end{tabular}

FIGURE 2 | Depicts of downstream signaling of chemoattractant receptors in GVHD. Signaling by chemokine receptors is mediated by heterotrimeric G-proteins. Activation of $\mathrm{G}$-proteins leads to activation of $\mathrm{Pl}_{3} \mathrm{~K}$, JAK, STAT, and MAPK. In GVHD, activation of $\mathrm{PI}_{3} \mathrm{~K} \gamma, \mathrm{JAK}$, STAT-1/3 leads to pro-inflammatory events that crucial to development of GVHD. STAT-3/STAT-1 activation preceded the activation of $\mathrm{NF}-\mathrm{\kappa B}$ and MAP kinases with the subsequent expression of IRF-1, SOCS-1, and IL-17. NF-KB has a dual role in development of GVHD, depending of phase of it expression. STAT-3 phosphorylation acts as a promoter of GVHD inflammation and is regulated by SOCS-3.
3 (JAK-3) have already been tested as a treatment for GVHD. The use of the JAK-3 inhibitor, WHI-P131 [4-(4'-hydroxyphenyl)amino-6,7-dimethoxyquinazoline], showed improved mortality rates and decreased liver and skin damage (Cetkovic-Cvrlje et al., 2001; Uckun et al., 2002). Another JAK-3 inhibitor, 4(3'-hydroxyphenyl)-amino-6,7-dimethoxyquinazoline (JANEX3 ), improved mortality rates and ameliorated the clinical symptoms of GVHD (Cetkovic-Cvrlje et al., 2002). A specific Bruton's tyrosine kinase (BTK) inhibitor (LFM-A13), was also tested as a treatment for GVHD; treated mice showed increased survival rates and had less clinical GVHD. The combined treatment of LFM-A13 with JANEX-3 was more effective than treatment with LFM-A13 or JANEX-3 alone (Cetkovic-Cvrlje and Uckun, 2004). Taken together, these results indicate that signaling molecules downstream of chemokine signaling may be useful targets for treating GVHD.

\section{GRAFT VERSUS LEUKEMIA}

In the context of the treatment of hematological malignances, such as leukemia, engraftment of donor cells is important to restore the immune system after ablative therapy (Kolb, 2008). In addition to reconstructing the immune system, the engrafted cells are thought to contribute to chemotherapy by inducing an anti-tumor effect, an effect that is known as (GVL; Rezvani and Barrett, 2008). Several therapies that decrease GVHD may decrease GVL, which is an undesirable outcome of such therapies (Rezvani and Barrett, 2008). Therefore, it is generally accepted that, in the context of haematopoietic stem cell transplantation, a therapy should decrease or prevent GVHD but ideally should not modify the associated GVL (Kolb, 2008; Rezvani and Barrett, 2008).

Although the chemokine system represents a promising system to target to develop new GVHD therapies, it is also important to understand the role of chemokines in GVL response. Evaluation of GVL has not been the major focus of studies involving chemokines and GVHD. However, we have found a few studies showing that, by interfering with the chemokine system, it is possible to decrease GVHD without interfering with GVL.

Our group (Castor et al., 2010) and Choi et al. (2007) demonstrated that, despite the important action of CCR1 and its ligands, CCL3, and CCL5, in the GVHD response, neutralization of CCL3, or the absence of CCR1 in donor cells did not interfere with GVL (Castor et al., 2010; Choi et al., 2007). The capacity of T cells to eliminate tumor cells remained unaltered upon neutralization of CCL3 by evasin-1 in mice subjected to GVHD (Castor et al., 2010). The absence of CCR1 in donor cells also maintained the GVL response in mice subjected to GVHD (Choi et al., 2007). Ueha et al. (2007) verified the GVL response in a study investigating the role of fractalkine (CX3CL1) in GVHD. In this study, CX3CL1 was important for GVHD development, but not for the GVL response, and treatment with anti-CX3CL1 decreased GVHD without modifying GVL. The same result was observed when a downstream chemokine receptor molecule, $\mathrm{PI}_{3} \mathrm{~K} \gamma$, was absent in donor cells. Transplantation of $\mathrm{PI}_{3} \mathrm{~K} \gamma$-deficient splenocytes reduced the ability of these cells to react against the host, but not against the tumor (Castor et al., 2011). 
The results described above indicate that the clinical use of inhibitors of these molecules may decrease the GVHD reaction but not interfere with GVL responses.

\section{CONCLUDING REMARKS}

The explicit participation of chemokines in the pathophysiology of different diseases has initiated the development of pharmacological strategies that can interfere with the chemokine system. Chemokines function by signaling through seven transmembrane G-protein-coupled receptors, which are one of the most druggable classes of receptors in the pharmaceutical industry (Horuk and Proudfoot, 2009).

Since 1996, interest in targeting the chemokine system has been growing, especially after demonstration of the participation of CCR5 as a co-receptor of HIV infection (Liu et al., 1996; Samson et al., 1996). After those studies, the pharmaceutical industry began investing in the development of molecules that could interfere with chemokine/chemokine receptor interaction. Examples of such molecules include chemokine receptor antagonists (Hesselgesser et al., 1998; White et al., 1998; Horuk and Proudfoot, 2009; Garin and Proudfoot, 2011), modified chemokines that act as antagonist molecules (Proudfoot et al., 1999, 2010), neutralizing antibodies to the chemokines or their receptors (Gonzalo et al., 1998) and chemokine binding proteins (Alcami, 2003; Smith et al., 2005; Frauenschuh et al., 2007; Déruaz et al., 2008; Russo et al., 2010). In 2007, the FDA approved maraviroc, an inhibitor of CCR5 for the prevention of HIV infection, which was the first triumph for a small-molecule drug acting on the chemokine system. A second small-molecule drug, a CXCR4 antagonist for haematopoietic stem cell mobilization, was approved by the FDA at the end of 2008. The results of a Phase III trial with a CCR9 inhibitor for Crohn's disease are also promising. The latter drug could represent the first success for a chemokine receptor antagonist to be used as an anti-inflammatory therapeutic. Development of this small-molecule drug confirms the importance of chemokine receptors as a target class for anti-inflammatory and autoimmune diseases (Proudfoot et al., 2010; Garin and Proudfoot, 2011).

\section{REFERENCES}

Addison, C. L., Daniel, T. O., Burdick, M. D., Liu, H., Ehlert, J. E., and Xue, Y. Y. (2000). The CXC chemokine receptor 2, CXCR2, is the putative receptor for ELR + CXC chemokine-induced angiogenic activity. J. Immunol. 165, 5269-5277.

Alcami, A. (2003). Viral mimicry of cytokines, chemokines and their receptors. Nat. Rev. Immunol. 3, 36-50.

Asavaroengchai, W., Wang, H., Wang, S., Wang, L., Bronson, R., Sykes, M., and Yang, Y. (2007). An essential role for IFN- $\gamma$ in regulation of alloreactive CD8 $\mathrm{T}$ cells following an allogeneic hematopoietic cell transplantation. Biol. Blood Marrow Transplant. 13, 46-55.

Baker, M. B., Altman, N. H., Podack, E. R., and Levy, R. B. (1996). The

There are many difficulties in translating beneficial results from murine studies to humans, one of which is the many caveats and differences between disease in experimental models and humans. Humans undergoing BMT have a primary disease and are subjected to immunosuppressive treatments before and during the transplantation. The usual conditioning regimen in humans, which consists of chemotherapy and radiation, is not always used. The source of donor cells and genetic and immunological disparities are also different from most animal models. Infectious challenges are not usually performed in conjunction with experimental induction of GVHD, but infections are commonly observed in immunosuppressed patients. Human microbiota is markedly different from the microbiota of a mouse kept in a pathogen-free facility, and bacterial translocation and sepsis are important causes of death in GVHD patients. Finally, young mice are usually used in experimental GVHD induction, but GVHD is generally more common in older people. These differences should not hamper development of drugs against GVHD but do not need to be taken into consideration when moving drugs forward into clinical trials.

Fewer studies have been performed to validate the use of inhibitors of the chemokine system in experimental GVHD. In this context, Evasin-1 (CCL3-CBP), CXCR3 antagonists, anti-CX ${ }_{3}$ CL1, inhibitor of CCR5 and CCR9 (CCX282), oligopeptides, such as NR58-3143, and inhibitors of molecules involved in downstream signaling of chemokine receptors $\left(\mathrm{PI}_{3} \mathrm{~K} \gamma\right.$, STAT-1 and 3, JAKs, and SOCS-1 and 3) decrease GVHD in mice and may hence represent an interesting clinical approach in humans. However, to the best of our knowledge, there are no studies confirming the effects of inhibitors of the chemokine system in GVHD in humans. Many experimental studies have not clarified the mechanism by which abrogation of inflammatory responses occur after use of therapies based on chemokine inhibition. Therefore, more mechanistic studies are needed to understand in greater detail the use of these therapeutic molecules in experimental GVHD. As mentioned above, any therapy for GVHD should decreased clinical disease but not interfere with GVL. In this respect, strategies based on CCL3, CCL5, and CX ${ }_{3}$ CL1 appear to be the most promising approach based on the existing experimental systems.

Holler, E. (2009). Chemokine and chemokine receptor expression analysis in target organs of acute graft-versus-host disease. Genes Immun. 10 687-701.

Braun, M. Y., Lowin, B., French, L., Acha-Orbea, H., and Tschopp, J. (1996) Cytotoxic T cells deficient in both functional fas ligand and perforin show residual cytolytic activity yet lose their capacity to induce lethal acute graftversus-host disease. J. Exp. Med. 183, 657-661.

Broxmeyer, H. E. (2008). Chemokines in hematopoiesis. Curr. Opin. Hematol. 15, 49-58.

Broxmeyer, H. E., Orschell, C. M., and Clapp, D. W. (2005). Rapid mobilization of murine and human hematopoietic stem and progenitor cells with AMD3100, a CXCR4 antagonist. J. Exp. Med. 201, 1307-1318.

Calcaterra, C., Sfondrini, L., Rossini, A., Sommariva, M., Rumio, C., Menard, S., and Balsari, A. (2008). Critical role of TLR9 in acute graft-versus-host disease. $J$. Immunol. 181, 6132-6139.

Carlson, M. J., Fulton, L. M., Coghillm, J. M., West, M. L., Burgents, J. E., Wan, Y., Panoskaltsis-Mortari, A., Tedder, T. F., Blazar, B. R., and Serody, J. S. (2010). L-selectin is dispensable for $\mathrm{T}$ regulatory cell function postallogeneic bone marrow transplantation. Am. J. Transplant. 10, 2596-2603.

Castor, M. G. M., Rezende, B., Bernardes, P. T. T., Vieira, T. A., Arantes, R. M. E., Souza, D. G., Silva Teixeira, M. M., and Pinho, 
V. (2011). PI3K $\gamma$ controls leukocyte recruitment, tissue injury and lethality in a model of graft versus host disease in mice. J. Leukoc. Biol. 89, 955-964.

Castor, M. G. M., Rezende, B., Resende, C. B., Alessandri, A. L., Fagundes, C. T., de Sousa, L. P., Arantes, R. M. E., Souza, D. G., Silva, T. A., Proudfoot, A. E., Teixeira, M. M., and Pinho, V. (2010). The CCL3/MIP-1 $\alpha$ binding protein evasin-1 protects from graft-versus-host disease but does not modify graft-versus-leukemia in mice. J. Immunol. 184, 2646-2654.

Cetkovic-Cvrlje, M., Roers, B. A., Schonhoff, D., Waurzyniak, B., Liu, X. P., and Uckun, F. M. (2002). Treatment of post-bone marrow transplant acute graft-versus-host disease with a rationally designed JAK3 inhibitor. Leuk. Lymphoma 43, 1447-1453.

Cetkovic-Cvrlje, M., Roers, B. A., Waurzyniak, B., Liu, X., and Uckun, F. M. (2001). Targeting Janus kinase 3 to attenuate the severity of acute graft-versus-host disease across the major histocompatibility barrier in mice. Blood 98, 1607-1613.

Cetkovic-Cvrlje, M., and Uckun, F. M. (2004). Dual targeting of Bruton's tyrosine kinase and Janus kinase 3 with rationally designed inhibitors prevents graft-versus-host disease (GVHD) in a murine allogeneic bone marrow transplantation model. Br. J. Haematol. 126, 821-827.

Chakraverty, R., Coté, D., Buchli, J., Cotter, P., Hsu, R., Zhao, G., Sachs, T., Pitsillides, C. M., Bronson, R., Means, T., Lin, C., and Sykes, M. (2006). An inflammatory checkpoint regulates recruitment of graftversus-host reactive $\mathrm{T}$ cells to pheripheral tissues. J. Exp. Med. 203, 2021-31.

Charo, I. F., and Ransohoff, R. M. (2006). The many roles of chemokines and chemokines receptors in inflammation. N. Engl. J. Med. 354, 610-621.

Choi, J. H., Yoon, H., Min, C., and Choi, E. Y. (2011). Effects of preconditioning dose on the immune kinetics and cytokine production in the leukocytes infiltrating GVHD tissues after MHC-matched transplantation. Immune Netw. 1, 68-78.

Choi, S. W., Hildebrandt, G. C., Olkiewicz, K. M., Hanauer, D. A., Chaudhary, M. N., Silva, I. A., Rogers, C. E., Deurloo, D. T., Fisher, J. M., Liu, C., Adams, D., Chensue, S. W., and Cooke, K. R. (2007). CCR1:CCL5 (RANTES) receptor ligand interactions modulates allogeneic $\mathrm{T}$ cell responses and reduces graft-versus-host disease following stem cell transplantation. Blood 110, 3447-3455.

Choi, S. W., Levine, J. E., and Ferrara, J. L. M. (2010). Pathogenesis and management of graft-versushost disease. Immunol. Allergy Clin. North Am. 30, 75-101.

Cooke, K. R., Krenger, W., Hill, G., Martin, T. R., Kobzik, L., and Brewer, J. (1998). Host reactive donor T cells are associated with lung injury after experimental allogeneic bone marrow transplantation. Blood 92, 2571-2580.

Cyster, J. G. (1999). Chemokines, and cell migration in secondary lymphoid organs. Science 286, 2098-2102.

Déruaz, M., Frauenschuh, A., Alessandri, A. L., Dias, J. M., Coelho, F. M., Russo, R. C., Ferreira, B. R., Graham, G. J., Shaw, J. P., Wells, T. N., Teixeira, M. M., Power, C. A., and Proudfoot, A. E. (2008). Ticks produce highly selective CBPs with antiinflammatory activity. J. Exp. Med. 205, 2019-2031.

Devetten, M. P., and Vose, J. M. (2004). Graft-versus-host disease: how to translate new insights into new therapeutic strategies. Biol. Blood Marrow Transplant. 10, 815-825.

Devine, S. M., Vij, R., Rettig, M., Todt, L., McGlauchlen, K., Fisher, N., Devine, H., Link, D. C., Calandra, G., Bridger, G., Westervelt, P., and Dipersio, J. F. (2008). Rapid mobilization of functional donor hematopoietic cells without G-CSF using AMD3100, an antagonist of the CXCR4/SDF-1 interaction. Blood 112, 990-998.

Duffner, U., Lu, B., Hildebrandt, G. C., Teshima, T., Williams, D. L., and Reddy, P. (2003). Role of CXCR3induced donor T-cell migration in acute GVHD. Exp. Hematol. 31, 897-902.

Durakovic, N., Bezak, K. B., Skarica, M., Radojcic, V., Fuchs, E. J., Murphy, G. F., and Luznik, L. (2006). Host-derived Langerhans cells persist after MHC-matched allografting independent of donor $\mathrm{T}$ cells and critically influence the alloresponses mediated by donor lymphocyte infusions. J. Immunol. 177, 4414-4425.

Faaij, C. M., Lankester, A. C., Spierings, E., Hoogeboom, M., Bowman, E. P., and Bierings, M. (2006). A possible role for CCL27/CTACK-CCR10 interaction in recruiting $\mathrm{CD} 4 \mathrm{~T}$ cells to skin in human graft-versushost disease. Br. J. Haematol. 133, 538-549.
Ferrara, J. L. (1993). Cytokine dysregulation as a mechanism of graftversus-host disease. Curr. Opin. Immunol. 5, 794-799.

Ferrara, J. L., Levine, J. E., Reddy, P., and Holler, E. (2009). Graft-versus-host disease. Lancet 373, 1550-1561.

Ferrara, J. L. M., and Reddy, P. (2006). Pathophysiology of graftversus-host disease. Semin. Hematol. 43, 3-10.

Flier, J., Boorsma, D. M., van Beek, P. J., Nieboer, C., Stoof, T. J., and Willemze, R. (2001). Differential expression of CXCR3 targeting chemokines CXCL10, CXCL9, and CXCL11 in different types of skin inflammation. J. Pathol. 194, 398-405.

Frauenschuh, A., Power, A. C., Déruaz, M., Ferreira, B., Teixeira, M. M., Martin, T., Wells, T. N. C., and Proudfoot, A. E. I. (2007). Molecular cloning and characterization of a highly selective chemokinebinding protein from the tick Rhipicephalus sanguineus. J. Biol. Chem. 282, 27250-27258.

Garin, A., and Proudfoot, A. E. (2011). Chemokines as targets for therapy. Exp. Cell Res. 10, 602-612.

Goker, H., Hanznedaroglu, I. C., and Chao, N. J. (2001). Acute graft-vshost disease: pathobiology and management. Exp. Hematol. 29, 259-277.

Gonzalo, J. A., Lloyd, C. M., Wen, D. Albar, J. P., Wells, T. N., Proudfoot, A., Martinez-A, C., Dorf, M., Bjerke, T., Coyle, A. J., and GutierrezRamos, J. C. (1998). The coordinated action of CC chemokines in the lung orchestrates allergic inflammation and airway hyperresponsiveness. $J$. Exp. Med. 188, 157-167.

Grainger, D. J., and Reckless, J. (2003). Broad-spectrum chemokine inhibitors (BSCIs) and their antiinflammatory effects in vivo. Biochem. Pharmacol. 65, 1027-1034.

Greenbaum, A. M., and Link, D. C. (2011). Mechanisms of G-CSF mediated hematopoietic stem and progenitor mobilization. Leukemia $25,211-217$.

Hadeiba, H., Sato, T., Habtezion, A., Oderup, C., Pan, J., and Butcher, E. C. (2008). CCR9 expression defines tolerogenic plasmacytoid dendritic cells able to suppress acute graftversus-host disease. Nat. Immunol. 9 , 1253-1260.

Hasegawa, H., Inoue, A., Kohno, M., Lei, J., Miyazaki, T., and Yoshie, O. (2008). Therapeutic effect of CXCR3-expressing regulatory $\mathrm{T}$ cells on liver, lung and intestinal damages in a murine acute GVHD model. Gene Ther. 15, 171-182.
Hesselgesser, J., Ng, H. P., Liang, M., Zheng, W., May, K., Bauman, J. G., Monahan, S., Islam, I., Wei, G. P., Ghannam, A., Taub, D. D., Rosser M., Snider, R. M., Morrissey, M. M., Perez, H. D., and Horuk, R. (1998). Identification and characterization of small molecule functional antagonists of the CCR1 chemokine receptor. J. Biol. Chem. 273, 15687-15692.

Hildebrandt, G. C., Corrion, L. A., Olkiewicz, K. M., Lu, B., Lowler, K., and Duffner, U. A. (2004a). Blockade of CXCR3 receptor:ligand interactions reduces leukocyte recruitment to the lung and the severity of experimental idiopathic pneumonia syndrome. J. Immunol. 173, 2050-2059.

Hildebrandt, G. C., Duffner, U. A., Olkiewicz, K. M., Corrion, L. A. Willmarth, N. E., and Williams, D. L. (2004b). A critical role for CCR2/MCP-1 interactions in the development of idiopathic pneumonia syndrome after allogeneic bone marrow transplantation. Blood 103, 2417-2426.

Hildebrandt, G. C., Olkiewicz, K. M., Corrion, L. A., Chang, Y., Clouthier, S. G., and Liu, C. (2004c). Donor derived TNF-alpha regulates pulmonary chemokine expression and the development of idiopathic pneumonia syndrome after allogeneic bone marrow transplantation. Blood 104, 586-593.

Hildebrandt, G. C., Olkiewicz, K. M., Choi, S., Corrion, L. A., Clouthier, S. G., Liu, C., Serody, J. S., and Cooke, K. R. (2005). Donor T-cell production of RANTES significantly contributes to the development of idiopathic pneumonia syndrome after allogeneic stem cell transplantation. Blood 105, 2249-2257.

Hildebrandt, G. C., Olkiewicz, K. O, Corrion, L. A., Chang, Y., Liu, C., and Ferrara, J. L. M. (2003). Secretion of TNF-alpha by donor effector cells is critical in the development of idiopathic pneumonia syndrome after allogeneic stem cell transplantation. Blood 102, 3529.

Hill, G. R., Crawford, J. M., Cooke, K. R., Brinson, Y. S., Pan, L., and Ferrara, J. L. (1997). Total body irradiation and acute graft-versus-host disease: the role of gastrointestinal damage and inflammatory cytokines. Blood 90, 3204-3213.

Hill, G. R., Kuns, R. D., Raffelt, N. C., Don, A. L., Olver, S. D., Markey, K. A., Wilson, Y. A., Tocker, J., Alexander, W. S., Clouston, A. D., Roberts, A. W., and MacDonald, K. P. (2010). SOCS3 regulates graft-versus-host disease. Blood 116, 287-296. 
Hogg, N., Henderson, R., Leitinger, B., McDowall, A., Porter, J., and Stanley, P. (2002). Mechanisms contributing to the activity of integrins on leukocytes. Immunol. Rev. 186, 164-171.

Hogg, N., Laschinger, M., Giles, K., and McDowall, A. (2003). T cell integrins: more than just sticking points. J. Cell. Sci. 116, 4695-4705.

Horuk, R., and Proudfoot, A. E. (2009). Drug discovery targeting the chemokine system - where are we? Front. Biosci. (Elite Ed.) 1, 209-219.

Howard, J. G., and Woodruff, M. F. A. (1961). Effect of the graft-versushost reaction on the immunological responsiveness on the mouse. Proc. R. Soc. Lond. B Biol. Sci. 154, 532-539.

Ichiba, T., Teshima, T., Kuick, R., Misek, D. E., Liu, C., and Takada, Y. (2003). Early changes in gene expression profiles of hepatic GVHD uncovered by oligonucleotide microarrays. Blood 102, 763-771.

Jaksch, M., and Mattsson, J. (2005). The pathophysiology of acute graft-versus-host disease. Scand. J. Immunol. 61, 398-409.

Johnson, B. D., Becker, E. E., and Truitt, R. L. (1999). Graft-vs.host and graft-vs.-leukemia reactions after delayed infusions of donor T-subsets. Biol. Blood Marrow Transplant. 5, 123-132.

Johnson, B. D., Hanke, C. A., and Truitt, R. L. (1996). The graft-versusleukemia effect of post-transplant donor leukocyte infusion. Leuk. Lymphoma 23, 1-9.

Kittan, N. A., and Hildebrandt, G. C. (2010). The chemokine system: a possible therapeutic target in acute graft-versus-host disease. Curr. Top. Microbiol. Immunol. 341, 97-120.

Kolb, H. J. (2008). Graft-versusleukemia effects of transplantation and donor lymphocytes. Blood 112, 4371-4379.

Krenger, W., Hill, G. R., and Ferrara, J. L. M. (1997). Cytokine cascades in acute graft-versus-host disease. Transplantation 27, 553-558.

Krenger, W., Rossi, S., Piali, L. and Hollander, G. A. (2000). Thymic atrophy in murine acute graft-versushost disease is effected by impaired cell cycle progression of host pro-T and pre-T cells. Blood 96, 347-354.

Lapp, W. S., Ghayur, T., Mendes, M., Seddik, M., and Seemayer, T. A. (1985). The functional and histological basis for graft-versushost induced immunosuppression. Immunol. Rev. 88, 107-133.

Ley, K., and Kansas, G. S. (2004). Selectins in T-cell recruitment to non-lymphoid tissues and sites of inflammation. Nat. Rev. Immunol. 4, 325-335.

Liu, R., Paxton, W. A., Choe, S., Ceradini, D., Martin, S. R., Horuk, R., Macdonald, M. E., Stuhlmann, H., Koup, R. A., and Landau, N. R. (1996). Homozygous defect in HIV1 coreceptor accounts for resistance of some multiply-exposed individuals to HIV-1 infection. Cell 86, 367-377.

Lu, S. X., Alpdogan, O., Lin, J., Balderas, R., Campos-Gonzalez, R., Wang, X., Gao, G., Suh, D., King, C., Chow, M., Smith, O., Hubbard, V. M., Bautista, J. L., Perez, J. C., Zakrzewski, J. L., Kochman, A. A., Chow, A., AltanBonnet, G., and van den Brink, M. R. (2008). STAT-3 and ERK 1/2 phosphorylation are critical for T-cell alloactivation and graft-versus-host disease. Blood 112, 5254-5258.

Lu, S. X., Holland, A. M., Na, I. K., Terwey, T. H., Alpdogan, O., Bautista, J. L., Smith, O. M., Suh, D., King, C., Kochman, A., Hubbard, V. M., Rao, U. K., Yim, N., Liu, C., Laga, A. C., Murphy, G., Jenq, R. R., Zakrzewski, J. L., Penack, O., Dykstra, L., Bampoe, K., Perez, L., Furie, B., Furie, B., and van den Brink, M. R. (2010). Absence of P-selectin in recipients of allogeneic bone marrow transplantation ameliorates experimental graftversus-host disease. J. Immunol. 185, 1912-1919.

Luster, A. D., Alon, R., and Von Andrian, U. H. (2005). Immune cell migration in inflammation: present and future therapeutic targets. Nat. Immunol. 6, 1182-1190.

Ma, H., Ziegler, J., Li, C., Sepulveda, A., Bedeir, A., Grandis, J., Lentzsch, S., and Mapara, Y. M. (2011). Sequential activation of inflammatory signaling pathways during graft-versushost disease (GVHD): early role for STAT1 and STAT3. Cell. Immunol. 268, 37-46.

Mackay, C. R. (2001). Chemokines: immunology's high impact factors. Nat. Immunol. 2, 95-101.

Mapara, M. Y., Leng, C., Kim, Y., Bronson, R., Lokshin, A., Luster, A., and Sykes, M. (2006). Expression of chemokines in GVHD target organs in influenced by conditioning and genetic factors and amplified by GVHR. Biol. Blood Marrow Transplant. 12, 623-634.

Merad, M., Hoffmann, P., Ranheim, E., Slaymaker, S., Manz, M. G., and Lira, S. A. (2004). Depletion of host Langerhans cells before transplantation of donor alloreactive T cells prevents skin graft versus-host disease. Nat. Med. 10, 510-517.
Merad, M., Manz, M. G., Karsunky, H., Wagers, A., Peters, W., and Charo, I. (2002). Langerhans cells renew in the skin throughout life under steady-state conditions. Nat. Immuol. 3, 1135-1141.

Miklos, S., Mueller, G., Chang, Y., Bouazzaoui, A., Spacenko, E., and Schubert, T. E. (2009). Preventive usage of broad spectrum chemokine inhibitor NR58-3.14.3 reduces the severity of pulmonary and hepatic graft-versus-host disease. Int. J. Hematol. 89, 383-397.

Moll, N. M., and Ransohoff, R. M. (2010). CXCL12 and CXCR4 in bone marrow physiology. Expert Rev. Hematol. 3, 315-322.

Moser, B., Wolf, M., Walz, A., and Loetscher, P. (2004). Chemokines: multiple levels of leukocyte migration control. Trends Immunol. 25, 75-84.

Muller, G., Hopken, U. E., and Lipp, M. (2003). The impact of CCR7 and CXCR5 on lymphoid organ development and systemic immunity. Immunol. Rev. 195, 117-135.

Murai, M., Yoneyama, H., Harada, A., Yi, Z., Vestergaard, C., and Guo, B. (1999). Active participation of CCR5(+)CD8(+) T lymphocytes in the pathogenesis of liver injury in graft-versus-host disease. J. Clin. Invest. 104, 49-57.

Murai, M., Yoneyama, H., Ezaki, T., Suematsu, M., Terashima, Y., and Harada, A. (2003). Peyer's patch is the essential site in initiating murine acute and lethal graft-versus-host reaction. Nat. Immunol. 4, 154-160.

Murphy, P. M. (2002). International Union of Pharmacology. XXX. Update on chemokine receptor nomenclature. Pharmacol. Rev. 54, 227-229.

Murphy, P. M., Baggiolini, M., Charo, I. F., Hebert, C. A., Horuk, R., and Matsushima, K. (2000). International Union of Pharmacology. XXII. Nomenclature for chemokine receptors. Pharmacol. Rev. 52, 145-176.

New, J. Y., Li, B., Koh, W. P., Ng, H. K., Tan, S. Y., and Yap, E. H. (2002). T cell infiltration and chemokine expression: relevance to the disease localization in murine graft-versus-host disease. Bone Marrow Transplant. 29, 979-986.

Ohl, L., Henning, G., Krautwald, S., Lipp, M., Hardtke, S., and Bernhardt, G. (2003). Cooperating mechanisms of CXCR5 and CCR7 in development and organization of secondary lymphoid organs. J. Exp. Med. 197, 1199-1204.

Palmer, L. A., Sale, G. E., Balogun, J. I., Li, D., Jones, D., Molldrem,
J. J., Storb, R. F., and Ma, Q (2010). Chemokine receptor CCR5 mediates alloimmune responses in graft-versus-host disease. Biol. Blood Marrow Transplant. 16, 311-319.

Panoskaltsis-Mortari, A., Strieter, R. M., Hermanson, J. R., Fegeding, K. V., Murphy, W. J., and Farrell, C. L. (2000). Induction of monocyteand T-cell-attracting chemokines in the lung during the generation of idiopathic pneumonia syndrome following allogeneic murine bone marrow transplantation. Blood 96, 834-839.

Park, H. B., Oh, K., Garma, N., Seo, M. W., Byoun, O. J., Lee, H. Y., and Lee, D. S. (2010). CP-690550, a Janus kinase inhibitor, suppresses CD4+ T-cell-mediated acute graftversus-host disease by inhibiting the interferon- $\gamma$ pathway. Transplantation 90, 825-835.

Pease, J. E., and Horuk, R. (2009). Chemokine receptor antagonists: part 2. Expert Opin. Ther. Pat. 19, 199-221.

Piper, K. P., Horlock, C., Curnow, S. J., Arrazi, J., Nicholls, S., and Mahendra, P. (2007). CXCL10CXCR3 interactions play an important role in the pathogenesis of acute graft-versus-host disease in the skin following allogeneic stemcell transplantation. Blood 110, 3827-3832.

Proudfoot, A. E., Buser, R., Borlat, F., Alouani, S., Soler, D. Offord, R. E., Schroder, J. M., Power, C. A., and Wells, T. N. (1999). Amino-terminally modified RANTES analogues demonstrate differential effects on RANTES receptors. J. Biol. Chem. 274, 32478-32485.

Proudfoot, A. E., Power, C. A., and Schwarz, M. K. (2010). Antichemokine small molecule drugs: a promising future? Expert Opin. Investig. Drugs 19, 345-355.

Pusic, I., and DiPersio, J. F. (2008). The use of growth factors in hematopoietic stem cell transplantation. Curr. Pharm. Des. 14, 1950-1961.

Rao, A. R., Quinones, M. P., Garavito, E., Kalkonde, Y., Jimenez, F., and Gibbons, C. (2003). CC chemokine receptor 2 expression in donor cells serves an essential role in graftversus-hostdisease. J. Immunol. 171, 4875-4885.

Reckless, J., Tatalick, L. M., and Grainger, D. J. (2001). The pan-chemokine inhibitor NR583.14.3 abolishes tumour necrosis factor-alpha accumulation and leucocyte recruitment induced 
by lipopolysaccharide in vivo. Immunology 103, 244-254.

Reiss, Y., Proudfoot, A. E., Power, C. A., Campbell, J. J., and Butcher, E. C. (2001). CC chemokine receptor (CCR) 4 and the CCR10 ligand cutaneous $\mathrm{T}$ cell-attracting chemokine (CTACK) in lymphocyte trafficking to inflamed skin. J. Exp. Med. 194, 1541-1547.

Rezvani, K., and Barrett, J. (2008). Characterizing, and optimizing immune responses to leukemia antigens after allogeneic stem cell transplantation. Best Pract. Res. Clin. Haematol. 21, 437-453.

Ribas, C., Penela, P., Murga, C., Salcedo, A., García-Hoz, C., JuradoPueyo, M., Aymerich, I., and Mayor, F. Jr. (2007). The G protein-coupled receptor kinase (GRK) interactome: role of GRKs in GPCR regulation and signaling. Biochim. Biophys. Acta 1768, 913-922.

Rolink, A. G., and Gleichmann, E. (1983). Allosuppressor- and allohelper- $\mathrm{T}$ cells in acute and chronic graft-vs.-host (GVH) disease. III. Different Lyt subsets of donor $\mathrm{T}$ cells induce different pathological syndromes. J. Exp. Med. 158, 546-558.

Rollins, B. J. (1997). Chemokines. Blood 90, 909-928.

Rot, A., and Von Andrian, U. H. (2004). Chemokines in innate and adaptive host defense: basic chemokinese grammar for immune cells. Annu. Rev. Immunol. 22, 891-928.

Russo, R. C., Garcia, C. C., and Teixeira, M. M. (2010). Anti-inflammatory drug development: broad or specific chemokine receptor antagonists? Curr. Opin. Drug Discov. Devel. $13,414-427$.

Samson, M., Libert, F., Doranz, B. J., Rucker, J., Liesnard, C., Farber, C. M., Saragosti, S., Lapoumeroulie, C., Cognaux, J., Forceille, C., Muyldermans, G., Verhofstede, C., Burtonboy, G., Georges, M., Imai, T., Rana, S., Yi, Y., Smyth, R. J., Collman, R. G., Doms, R. W., Vassart, G., and Parmentier, M. (1996). Resistance to HIV-1 infection in caucasian individuals bearing mutant alleles of the CCR-5 chemokine receptor gene. Nature 382, 722-725.

Saruta, M., Yu, Q. T., Avanesyan, A., Fleshner, P. R., Targan, S. R., and Papadakis, K. A. (2007). Phenotype and effector function of $\mathrm{CC}$ chemokine receptor 9-expressing lymphocytes in small intestinal Crohn's disease. J. Immunol. 178, 3293-3300.
Sasaki, M., Hasegawa, H., Kohno, M., Inoue, A., Ito, M. R., and Fujita, S. (2003). Antagonist of secondary lymphoid-tissue chemokine (CCR ligand 21) prevents the development of chronic graft versus-host disease in mice. J. Immunol. 170, 588-596.

Sato, T., Thorlacius, H., Johnston, B., Staton, T. L., Xiang, W., and Littman, D. R. (2005). Role for CXCR6 in recruitment of activated CD8plymphocytes to inflamed liver. J. Immunol. 174, 277-283.

Schleuning, M. (2000). Adoptive allogeneic immunotherapy: history and future perspectives. Transfus. Sci. 23, 133-150.

Schmaltz, C., Alpdogan, O., and Horndasch, K. J. (2001). Differential use of Fas ligand and perforin cytotoxic pathways by donor $\mathrm{T}$ cells in graft-versus-host disease and graftversus-leukemia effect. Blood 97, 2886-2895.

Schroeder, M. A., and DiPersio, J. F. (2011). Mouse models of graftversus-host disease: advances and limitations. Dis. Model Mech. 4, 378-333.

Semerad, C. L., Christopher, M. J., and Liu, F. (2005). G-CSF potently inhibits osteoblast activity and CXCL12 mRNA expression in the bone marrow. Blood 106, 3020-3027.

Serody, J. S., Burkett, S. E., PanoskaltsisMortari, A., Ng-Cashin, J., McMahon, E., Matsushima, G. R., Lira, S. A., Cook, D. N., and Blazar, B. R. (2000). T-lymphocyte production of macrophage inflammatory protein- $1 \alpha$ is critical to recruitment of CD8+ T cells to the liver, lung, and spleen during graft-versus-host disease. Blood 96, 2973-2980.

Serody, J. S., Cook, D. N., Kirby, S. L., Reap, E., Shea, T. C., and Frelinger, J. A. (1999). Murine T lymphocytes incapable of producing macrophage inhibitory protein- $1 \alpha$ are impaired in causing graft-versus-host disease across a class I but not class II major histocompatibility complex barrier. Blood 93, 43-50.

Shlomchik, W. D. (2007). Graft-versushost disease. Nat. Rev. Immunol. 7 , 340-352.

Smith, P., Fallon, R. E., Mangan, N. E., Walsh, C. M., Saraiva, M., Sayers, J. R., Mckenzie, A. N., Alcami, A., and Fallon, P. G. (2005). Schistosoma mansoni secretes a chemokine binding protein with antiinflammatory activity. J. Exp. Med. 202, 1319-25.

Socié, G., and Blazar, B. R. (2009). Acute graft-versus-host disease; from the bench to the bedside. Blood 114, 4327-4336.

Sprent, J., Schaefer, M., Lo, D., and Korngold, R. (1986). Properties of purified $\mathrm{T}$ cell subsets. II. In vivo responses to class I vs. class II H-2 differences. J. Exp. Med. 163, 998-1011.

Strieter, R. M., Burdick, M. D. Gomperts, B. N., Belperio, J. A., and Keane, M. P. (2005). CXC chemokines in angiogenesis. Cytokine Growth Factor Rev. 16, 593-609.

Sun, K., Welniak, L. A., PanoskaltsisMortari, A., O'Shaughnessy, M. J. Liu, H., Barao, I., Riordan, W. Sitcheran, R., Wysocki, C., Serody, J. S., Blazar, B. B. R., Sayers, T. J., and Murphy, W. J. (2004). Inhibition of acute graft-versushost disease with retention of graft-versus-tumor effects by the proteasome inhibitor bortezomib. Proc. Natl. Acad. Sci. U.S.A. 101, 8120-8125.

Sun, K., Wilkins, D. E., Anver, M R., Sayers, T. J., PanoskaltsisMortari, A., Blazar, B. R., Welniak, L. A., and Murphy, W. J. (2005). Differential effects of proteasome inhibition by bortezomib on murine acute graft-versus-host disease (GVHD): delayed administration of bortezomib results in increased GVHD-dependent gastrointestinal toxicity. Blood 106 3293-3299.

Terwey, T. H., Kim, T. D., Kochman, A. A., Hubbard, V. M., Lu, S., and Zakrzewski, J. L. (2005). CCR2 is required for CD8-induced graftversus-host disease. Blood 106, 3322-3330.

Uckun, F. M., Roers, B. A., Waurzyniak, B., Liu, X., and CetkovicCvrlje, M. (2002). Janus kinase 3 inhibitor WHI-P131/JANEX-1 prevents graft-versus-host disease but spares the graft-versus-leukemia function of the bone marrow allografts in a murine bone marrow transplantation model. Blood 99, 4192-4199.

Ueha, S., Murai, M., Yoneyama, H., Kitabatake, M., Imai, T., and Shimaoka, T. (2007). Intervention of MAdCAM-1 or fractalkine alleviates graft-versus-host reaction associated intestinal injury while preserving graft-versustumor effects. J. Leukoc. Biol. 81, 176-185.

Varona, R., Cadenas, V., Lozano, M., Moreno-Ortiz, M. C., Kremer, L., and Martinez, A. C. (2006). CCR6 regulates the function of alloreactive and regulatory $\mathrm{CD} 4 \mathrm{pT}$ cells during acute graft-versushostdisease. Leuk. Lymphoma 47, 1469-1476.

Welniak, L. A., Blazar, B. R., and Murphy, W. J. (2007). Immunobiology of allogeneic hematopoietic stem cell transplantation. Annu. Rev. Immunol. 25, 139-170.

Welniak, L. A., Wang, Z., and Sun, K. (2004). An absence of CCR5 on donor cells results in acceleration of acute graft-vs-host disease. Exp. Hematol. 32, 318-324.

White, J. R., Lee, J. M., Young, P. R., Hertzberg, R. P., Jurewicz, A. J., Chaikin, M. A., Widdowson, K., Foley, J. J., Martin, L. D., Griswold, D. E., and Sarau, H. M. (1998) Identification of a potent, selective non-peptide CXCR2 antagonist that inhibits interleukin-8-induced neutrophil migration. J. Biol. Chem. 273, 10095-10098.

Will, A., and Wynn, R. (2006). Diagnosis of acute graft-versus-host disease. Transplantation 81, 505-506.

Wysocki, C. A., Burkett, S. B., Panoskaltsis-Mortari, A., Kirby, S. L., Luster, A. D., McKinnon, K., Blazar, B. R., and Serody, S. J. (2004). Differential roles for CCR5 expression on donor $\mathrm{T}$ cells during graft-versus-host disease based on pretransplant conditioning. J. Immunol. 173 , 845-854.

Wysocki, C. A., Panoskaltsis-Mortari, A., Blazar, B. R., and Serody, J. S. (2005). Leukocyte migration and graft-versus-host disease. Blood 105, 4191-4199.

Yakoub-Agha, I., Saule, P., Depil, S., Micol, J. B., Grutzmacher, C., and Boulanger-Villard, F. (2006). A high proportion of donor $\mathrm{CD} 4+\mathrm{T}$ cells expressing the lymph nodehoming chemokine receptor CCR7 increases incidence and severity of acute graft-versus-host disease in patients undergoing allogeneic stem cell transplantation for hematological malignancy. Leukemia 20 1557-1565.

Yi, T., Chen, Y., Wang, L., Du, G., Huang, D., Zhao, D., Johnston, H. Young, J., Todorov, I., Umetsu, D. T., Chen, L., Iwakura, Y., Kandeel, F., Forman, S., and Zeng, D. (2009). Reciprocal differentiation and tissue-specific pathogenesis of Th1, Th2, and Th17 cells in graft-versus-host disease. Blood 114, 3101-3112.

Zhang, Y., Joe, G., Hexner, E., Zhu, J., and Emerson, S. G. (2005). Alloreactive memory $\mathrm{T}$ cells are responsible for the persistence of graftversus-host disease. J. Immunol. 174, 3051-3058. 
Zlotnik, A., and Yoshie, O. (2000). Chemokines: a new classification system and their role in immunity. Immunity 12, 121-127.

Conflict of Interest Statement: The authors declare that the research was conducted in the absence of any commercial or financial relationships that could be construed as a potential conflict of interest.

Received: 28 November 2011; paper pending published: 21 December 2011; accepted: 08 February 2012; published online: 24 February 2012.

Citation: Castor MGM, Pinho V and Teixeira MM (2012) The role of chemokines in mediating graft versus host disease: opportunities for novel therapeutics. Front. Pharmacol. 3:23. doi: 10.3389/fphar.2012. 00023

This article was submitted to Frontiers in Experimental Pharmacology and Drug Discovery, a specialty of Frontiers in Pharmacology.
Copyright (c) 2012 Castor, Pinho and Teixeira. This is an open-access article distributed under the terms of the Creative Commons Attribution Non Commercial License, which permits noncommercial use, distribution, and reproduction in other forums, provided the original authors and source are credited. 